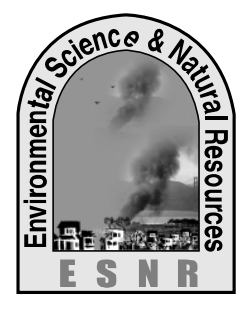

J. Environ. Sci. \& Natural Resources, 6(2): 227-231, 2013

ISSN 1999-7361

\title{
Comparison of Struvite Compost with other Fertilizers on Maize Fodder
} Production

\author{
M. A. Rahman, M. A. Hashem*, M. M. Rahman, S. M. E. Rahman, M. M. Hossain, M. A. \\ K. Azad and M. E. Haque ${ }^{1}$
}

Department Of Animal Science, Bangladesh Agricultural University, Mymensingh-2202, Bangladesh. ${ }^{1}$ Depertment of Animal Nutrition, Sylhet Agricultural University, Sylhet-3100.

\begin{abstract}
The present experiment was conducted to examine the effect of struvite compost, cowdung and urea on maize fodder production. The experiment was designed in a Completely Randomized Deign (CRD) with three replications. The treatments under study were $\mathrm{T}_{0}$-Control, $\mathrm{T}_{1}$-Struvite Compost @ 10MT/ha, $\mathrm{T}_{2}$-Cowdung @ 10MT/ha, $\mathrm{T}_{3}$-Urea@ 250kg/ha. The total biomass yields of maize fodder was significantly $(\mathrm{P}<0.01)$ higher in struvite composting $(6.88 \mathrm{t} / \mathrm{ha})$ treatment group over control $(3.03 \mathrm{t} / \mathrm{ha})$, cowdung (4.68 t/ha) and urea (6.78 t/ha). The plant height was similar and more in treated group than control but in case of plant diameter similar effect was observed when applied struvite compost and urea. Leaf area index was highest $\left(2018.11 \mathrm{~cm}^{2}\right)$ in struvite compost. The crude protein content was the highest (15.63\%) in struvite compost. In case of ether extract, similar effect was observed when applied struvite compost and urea. The highest value (3.60\%) was observed when cowdung was applied. In case of ash content, the similar effect was observed when applied struvite compost and cowdung. The potassium content of maize was significantly $(\mathrm{P}<0.01)$ higher in struvite compost $(35.54 \mathrm{ppm})$ treated group than control but in case of phosphorus content of maize fodder, similar effect was observed when applied struvite compost, urea and cowdung. The carbon content of post harvesting soil was significantly $(\mathrm{P}<0.05)$ higher in struvite compost group among other treated groups. The highest carbon content value $(2.03 \%)$ in the soil of struvite compost treated group indicates the maximum carbon sequestration occurred than all other treatments. The nitrogen content of post harvesting soil was significantly $(\mathrm{P}<0.05)$ higher in struvite compost treatment than control. Therefore, considering the above mentioned parameters, the application of struvite compost could be recommended for maize fodder production.
\end{abstract}

Key words: Comparison, Maize Fodder Production, Production, Struvite Compost

\section{Introduction}

In Bangladesh, farmers generally do not grow any crop exclusively as fodder because they have insufficient land to do so. Here cultivable land is mainly occupied by the crops which give direct benefit to farmers in terms of food and cash. At present 0.736 million hectares of cultivable land are laying fallow for more than one year and 8.697 million ha are unavailable for cultivation. About $84 \%$ of the cultivable land is used for cereal and only $0.05 \%$ for fodder production and the rest for other crops (BBS, 2005). As a result, forage-based livestock production becomes more difficult because of fodder shortage. Besides, there is no pasture land in our country and crop land is used as temporary pastures. Pasture lands have now been turned into crop fields due to the introduction of irrigation facilities. But we know, to achieve a continuous production of milk, fodder supply to the dairy cows in all the year round should be maintained. Struvite is crystallized magnesium ammonium phosphate (MAP, $\mathrm{MgNH} 4 \mathrm{PO} \cdot 6 \mathrm{H} 2 \mathrm{O}$ ) with magnesium and ammonium phosphate in equal molar concentrations; it is formed under alkaline conditions. It crystallizes in the orthorhombic system as white to yellowish or brownish-white pyramidal crystals or in platy micalike forms. It is a soft mineral with a low specific gravity of 1.7.The presence of magnesium makes struvite useful for sugar beets because sugar beet needs magnesium ions .Struvite recovered from waste waters acts as an environmentally friendly fertilizer. . Magnesium and phosphate salts may be used as a tool for struvite formation by a reaction with the NH4 of swine manure. It is known that during composting, when organic matter is actively decomposed, a large amount of nitrogen is emitted as ammonia (NH3). Presently, struvite is commercially produced by Unitika Limited in Japan and is already being sold to American fertilizer companies. Munch and Barr have described struvite's use commercially for container plants. Struvite is also used an appropriate fertilizer for pastures, tree seedlings, ornamentals, vegetables, and flower boards. Since it releases nutrients at a slower rate than soluble fertilizers throughout the season, plants can take up most of the nutrients without any waste via evaporation or leaching and consequently, less frequent application is required. Considering above view in mind, the present experiment was conducted to fulfill the following objects:

a. To compare the effect of struvite compost with urea and cowdung on the production of maize fodder.

b. To examine the effect of different fertilizers on the proximate and macro nutrient content of maize fodder. 
c. To estimate the effect of above fertilizer on post harvest soil quality.

\section{Materials and Methods}

The experiment was conducted to evaluate the contribution of struvite compost, cowdung and urea for maize fodder production as livestock feed. The materials used and methods followed for the experiments have been described under following sections.

\section{Experimental site}

The activities related to fodder production were conducted at the Sheep, Goat and Horse farm under the Department of Animal Science, Bangladesh Agricultural University, Mymensingh during the period of February 12 to April 13, 2012.

\section{Ecology of the experimental site Climatic condition}

The experimental site is situated at $24^{0} \mathrm{~N}$ latitude and $91^{0} \mathrm{E}$ longitudes having an altitude of $8.3 \mathrm{~m}$. The climate of the experimental site is subtropical in nature, which is characterized by three distinct seasons, the monsoon extending from May to October, the winter or dry season from November to February and pre-monsoon period hot season from March to April.

\section{Characteristics of soil}

The soil texture of the experimental site was silty loam, land was medium high and belongs to the Agro-Ecological Zone (AEZ-9) which was originated from Old Brahmaputra deposits, having noncalcareous dark grey flood plain soil (FAO,1988).

\section{Cultivation of maize fodder \\ Preparation of land}

The land was ploughed and cross ploughed four times with tractor drawn country plough followed by laddering to obtain the desirable tith. The corners of the land were spaded and divisible large clods were broken into small pieces. All the weeds and stubbles of the previous crop were removed and then the land was leveled and divided into 12 plots. Each plot was of $4 \mathrm{~m}^{2}(2 \mathrm{~m} \times 2 \mathrm{~m})$.

\section{Sowing of seeds and intercultural operation}

Maize was sown ( $40 \mathrm{~kg} / \mathrm{ha}$ ) in rows behind a plough maintaining a row spacing of $75 \mathrm{~cm}$ and seed spacing of $25 \mathrm{~cm}$ and depth was about 5 to $6 \mathrm{~cm}$. A slight spading was done for better soil covering of seeds. The seedlings of the fodder crop emerged out within 5-6 days after sowing (DAS). Necessary gap filling was done at 15 DAS. Weeding was done once for all plots and there after as and when needed.

\section{Gap filling}

Gap filling was done as and when required with the border plants kept for this purpose.

\section{Irrigation}

Irrigation was applied by observing the soil moisture condition. However, each top-dressing was followed by irrigation.

\section{Data Collection}

Plant sample

Plant samples were collected for recording the following data.

Green Biomass yield (ton/ha)

Plant height $(\mathrm{cm})$

Plant diameter $(\mathrm{cm})$

Number of leaves/plant

Leaf Area Index (LAI)

\section{Collection and preparation of fodder sample}

The plants were harvested above the ground level and immediately collected from the plot. The fodder plant individual plot was collected and tagged separately.

\section{Methods of data collection}

Three plants, from middle rows were selected for data collection from each unit plot. Data were recorded from sample plants during the period of experiment.

\section{Chemical analysis}

Samples were ground by grinding machine. The ground samples were bottled covered with aluminum foil and kept in desiccators. Chemical composition of samples for dry matter (DM), organic matter (OM) and nitrogen $(\mathrm{N})$ were determined by following the method of AOAC (1990).

\section{Plant sample collection \\ Harvesting of the fodder}

Maize fodder was harvested at pre flowering stage at the age of 60 days on April 13, 2013. All the yield of fodders were recorded by weighing balance and forage production under different levels of organic manure were recorded in metric ton/ha (MT/ha).

\section{Number of leaves and circumference of stem}

Number of leaves/plant, fodder height and diameter of per plant were measured on every 20 day. Three plants were collected randomly from 3 different places of replication and number of leaves/plant; fodder height and circumference were recorded. 


\section{Plant height}

The plant height was measured on every 20 day after sowing (DAS) and at harvest by using a meter scale. The measurement was taken from the ground level to the tip of the largest leaf of an individual plant. Mean value of the three selected plants was calculated for each unit plot and expressed in centimeter $(\mathrm{cm})$.

\section{Number of leaves/plant}

Three plants were randomly selected from each replication and total number of leaves was manually recorded.

\section{Green biomass yield per plot}

The gross weight of total plants of each replication was taken in kilogram $(\mathrm{kg})$ and was converted to MT/ha.

\section{Leaf Area Index $\left(\mathrm{cm}^{2}\right)$}

Three plants were randomly selected from each replication and total number of leaves was collected. Leaf area index are measured by Leaf Area Index meter and result was collected as $\mathrm{cm}^{2}$ in Bangladesh Agricultural University centre lab.

\section{Statistical analysis}

The recorded data on various parameters under study were statistically analyzed according to the Completely Randomized design to find out the variation resulting from experimental treatments using SAS software. The means for all the treatments were calculated and analysis of variance of each parameter was performed by the comparison of the treatment means was done by Duncan Multiple Range Test (DMRT) at $(\mathrm{P}<0.01)$.

\section{Results and Discussion}

Effects of struvite compost, cowdung and urea on the green biomass yield, number of leaves/ plant and leaf area index

The green biomass yield, number of plant leaves and leaf area index of maize were influenced significantly $(\mathrm{p}<0.01)$ due to application of struvite compost, cowdung and urea (Table 1). The highest green biomass yield was found in $T_{1}$ and the lowest biomass yield was found in $\mathrm{T}_{0} . \mathrm{T}_{1}, \mathrm{~T}_{2}$ and $\mathrm{T}_{3}$ produce statistically similar green biomass yield (Tareque. 1992; Haque. 2003). From the biomass yield, it is indicates that struvite compost was slowly released nutrient to maize fodder for their proper biomass production (Rahman et al. 2014). The highest number of plant leaves was observed in $\mathrm{T}_{3}$ and the lowest number of plant leaves was observed in $T_{0} . T_{1}, T_{2}$ and $\mathrm{T}_{3}$ produce statistically similar number of leaves. The highest leaf area index was found in $T_{1}$ which was statistically similar to $T_{2}$ and $T_{3}$ and the lowest leaf area index was found in $\mathrm{T}_{0}$ (Reddy et al. 1987).

Table 1. Effects of struvite compost, cowdung and urea on the green biomass yield, number of leaves per plant and leaf area index

\begin{tabular}{|c|c|c|c|c|c|}
\hline \multirow[b]{2}{*}{ Variables } & \multicolumn{4}{|c|}{ Treatments } & \multirow{2}{*}{$\begin{array}{l}\text { Level of } \\
\text { significance }\end{array}$} \\
\hline & $\mathrm{T}_{0}$ & $\mathrm{~T}_{1}$ & $\mathrm{~T}_{2}$ & $\mathrm{~T}_{3}$ & \\
\hline $\begin{array}{c}\text { Green biomass } \\
\text { yield(ton/ha) }\end{array}$ & $3.03^{\mathrm{b}} \pm 0.13$ & $6.88^{\mathrm{a}} \pm 0.80$ & $4.68^{\mathrm{ab}} \pm 0.75$ & $6.78^{\mathrm{a}} \pm 1.08$ & $* *$ \\
\hline $\begin{array}{c}\text { No of } \\
\text { leaves/plant }\end{array}$ & $7.10^{\mathrm{b}} \pm 0.62$ & $9.11^{\mathrm{a}} \pm 0.29$ & $8.11^{\mathrm{ab}} \pm 0.22$ & $9.55^{\mathrm{a}} \pm 0.89$ & $* *$ \\
\hline $\begin{array}{c}\text { Leaf area } \\
\text { index }\left(\mathrm{cm}^{2}\right)\end{array}$ & $961.55^{\mathrm{b}} \pm 248.05$ & $2018.11^{\mathrm{a}} \pm 188.21$ & $1642.31^{\mathrm{ab}} \pm 349.97$ & $1896.29^{\mathrm{ab}} \pm 289.48$ & $* *$ \\
\hline
\end{tabular}

Mean values having different superscript in the same row differ significantly. ${ }^{* *},(\mathrm{P}<0.01) . \mathrm{T}_{0}$-Control, $\mathrm{T}_{1}$-Struvite Compost @ 10MT/ha, T2-Cowdung @ 10MT/ha, T3-Urea@ 250kg/ha.

\section{Effect of struvite compost, cowdung and urea on plant height and plant diameter}

Number of leaves/plant and diameter of plant were influenced significantly due to $(\mathrm{p}<.01)$ application of urea, cowdung, and struvite compost (Table 1). The Highest plant height was observed in $\mathrm{T}_{3}$ and lowest the plant height was observed in $\mathrm{T}_{0}$. There was no significant difference between $T_{1}, T 2$, and $T_{3}(p>.01)$. On the other hand, the highest plant diameter was recorded in $\mathrm{T}_{3}$ and the lowest plant diameter was recorded in $\mathrm{T}_{0}$. There was no significant $(\mathrm{P}>01)$ difference between $\mathrm{T}_{1}$ and $\mathrm{T}_{3}, \mathrm{~T}_{2}$ and $\mathrm{T}_{0}$ (Reddy et al. 1987). 
Table 2. Effects of struvite compost, cowdung and urea on plant height and plant diameter

\begin{tabular}{|c|c|c|c|c|c|}
\hline \multirow[b]{2}{*}{ Variables } & \multicolumn{4}{|c|}{ Treatments } & \multirow{2}{*}{$\begin{array}{l}\text { Level of } \\
\text { significance }\end{array}$} \\
\hline & $\mathrm{T}_{0}$ & $\mathrm{~T}_{1}$ & $\mathrm{~T}_{2}$ & $\mathrm{~T}_{3}$ & \\
\hline Plant height $(\mathrm{cm})$ & $76.80^{\mathrm{b}} \pm 0.23$ & $112.63^{\mathrm{a}} \pm 3.92$ & $99.30^{\mathrm{a}} \pm 5.18$ & $116.43^{\mathrm{a}} \pm 10.16$ & $* *$ \\
\hline Plant Diameter $(\mathrm{cm})$ & $3.66^{\mathrm{c}} \pm 0.18$ & $4.79^{\mathrm{ab}} \pm 0.17$ & $4.18^{\mathrm{bc}} \pm 0.06$ & $4.88^{\mathrm{a}} \pm 0.32$ & ** \\
\hline
\end{tabular}

Mean values having different superscript in the same row differ significantly. $* *,(\mathrm{P}<0.01)$. $\mathrm{T}_{0}$-Control, $\mathrm{T}_{1}$-Struvite Compost @ 10MT/ha, T2-Cowdung @ 10MT/ha, T3-Urea@ 250kg/ha.

Effects of struvite compost, cowdung and urea on the proximate component of maize fodder

Crude protein content of maize fodder

Application of struvite compost, cowdung and urea resulted in significant $(\mathrm{P}<0.01)$ variation in crude protein of maize straw (Table 3). The highest crude protein content was observed in the treatment $T_{1}$ and the lowest crude protein content of maize straw was recorded in the control $\left(\mathrm{T}_{0}\right)$. Application of struvite compost increased the crude protein content of maize fodder straw markedly in $T_{1}$. There was statistical similarity between $T_{2}$ and $T_{3}$.

\section{Organic matter content of maize fodder}

Non-significant variation in the organic matter content in maize fodder was recorded due to the application of struvite compost, cowdung and urea (Table 3). The organic matter content was the highest in $\mathrm{T}_{1}$ and the lowest in $\mathrm{T}_{0}$ (Khandaker and Islam. 1998). The organic matter content was similar between $\mathrm{T}_{2}$ and $\mathrm{T}_{3}$.

\section{Dry matter content of maize fodder}

Non-significant variation in the dry matter content in maize fodder was recorded due to the application of struvite compost, cowdung and urea (Table 3). The dry matter content was the highest in $\mathrm{T}_{2}$ and the lowest in $\mathrm{T}_{0}$. There is no significant $(\mathrm{P}<0.05)$ difference between $T_{1}, T_{2}$ and $T_{3}$.

\section{Ether extracts content of maize fodder}

A significant $(\mathrm{P}<0.05)$ variation in the ether extract content in maize fodder was recorded due to the application of struvite compost, cowdung and urea (Table 3). The ether extract content was the highest in $\mathrm{T}_{2}$ and the lowest in $\mathrm{T}_{0}$. The ether extract content was statistically similar between $\mathrm{T}_{1}$ and $\mathrm{T}_{3}$.

\section{Ash content of maize fodder}

A significant $(\mathrm{P}<0.01)$ variation in the ash content in maize fodder was recorded due to the application of struvite compost, cowdung and urea (Table 3). The ash content was the highest in $\mathrm{T}_{2}$ and the lowest in $\mathrm{T}_{0}$ (Khandaker and Islam. 1998). There is no significant difference between $\mathrm{T}_{1}$ and $\mathrm{T}_{3}(\mathrm{P}>.01)$.

Table 3. Effects of struvite compost, cowdung and urea on the proximate component of maize fodder.

\begin{tabular}{|l|l|l|l|l|c|}
\hline \multirow{2}{*}{ Variables } & \multicolumn{4}{|c|}{ Treatment } & \\
\cline { 2 - 6 } & $\mathrm{T}_{0}$ & \multicolumn{1}{|l|}{$\mathrm{T}_{\mathrm{I}}$} & \multicolumn{1}{l|}{$\mathrm{T}_{2}$} & \multicolumn{1}{l|}{$\mathrm{T}_{3}$} & $\begin{array}{l}\text { Level of } \\
\text { significance }\end{array}$ \\
\hline CP\% & $10.62^{\mathrm{c}} \pm 0.06$ & $15.63^{\mathrm{a}} \pm 0.07$ & $12.31^{\mathrm{b}} \pm 0.12$ & $12.51^{\mathrm{b}} \pm 0.03$ & $* *$ \\
\hline OM\% & $86.53 \pm 4.26$ & $92.50 \pm 0.11$ & $90.60 \pm 0.05$ & $90.60 \pm 0.05$ & NS \\
\hline DM\% & $84.93 \pm 2.08$ & $87.50 \pm 0.05$ & $88.20 \pm 0.05$ & $86.70 \pm 0.11$ & NS \\
\hline EE\% & $0.40^{\mathrm{c}} \pm 0.05$ & $2.0^{\mathrm{b}} \pm 0.05$ & $3.60^{\mathrm{a}} \pm 0.05$ & $2.40^{\mathrm{a}} \pm 0.05$ & $*$ \\
\hline Ash\% & $7.70^{\mathrm{c}} \pm 0.05$ & $9.20^{\mathrm{ab}} \pm 0.05$ & $9.36^{\mathrm{a}} \pm 0.08$ & $9.10^{\mathrm{b}} \pm 0.05$ & $* *$ \\
\hline
\end{tabular}

Mean values having different superscript in the same row differ significantly. ${ }^{*},(\mathrm{P}<0.05),{ }^{* *},(\mathrm{P}<0.01) . \mathrm{T}_{0}$-Control, $\mathrm{T}_{1}-\mathrm{Struvite}$ Compost @ 10MT/ha, T2-Cowdung @ 10MT/ha, T -Urea@ 250kg/ha.

\section{Effects of struvite compost, cowdung and urea on} the post harvesting soil nutrients profile

The $\mathrm{P}^{\mathrm{H}}$ of the post harvesting soil was the highest in $\mathrm{T}_{0}$ and the lowest in $\mathrm{T}_{1}$ (Table 4). The carbon contents of the post harvesting soil nutrient profile were recorded significantly $(\mathrm{P}<0.05)$ highest in $\mathrm{T}_{1}$ and the lowest in $\mathrm{T}_{2}$. The carbon content was statistically similar among $\mathrm{T}_{0}, \mathrm{~T}_{2}$ and $\mathrm{T}_{3}$. The nitrogen percent of the post harvesting soil nutrient profile was recorded significantly $(\mathrm{P}<0.05)$ highest in $\mathrm{T}_{1}$ and the lowest in $T_{2}$. The nitrogen percent was statistically similar among $\mathrm{T}_{0}, \mathrm{~T}_{2}$ and $\mathrm{T}_{3}$ (Dhiman et al. 1982). The phosphorus contents of the post harvesting soil nutrient profile were recorded the highest in $T_{2}$ and the lowest in $T_{1}$ (Hammam. 1995). The potassium contents of the post harvesting soil nutrient profile were recorded significantly $(\mathrm{P}<0.01)$ highest in $\mathrm{T}_{1}$ and the lowest in $\mathrm{T}_{0}$ and $\mathrm{T}_{2}$ (Razende et al. 1994). The sulphar contents of the post harvesting 
soil nutrient profile were recorded significantly $(\mathrm{P}<0.05)$ highest in $\mathrm{T}_{1}$ and the lowest in $\mathrm{T}_{0}$. The sulphar content was statistically similar between $\mathrm{T}_{0}$ and $\mathrm{T}_{2}$

Table 4. Effects of struvite compost, cowdung and urea on the post harvesting soil nutrients profile

\begin{tabular}{|c|c|c|c|c|c|}
\hline \multirow{2}{*}{ Variables } & \multicolumn{4}{|c|}{ Treatment } & $\mathrm{T}_{3}$ \\
\cline { 2 - 6 } & $\mathrm{T}_{0}$ & $\mathrm{~T}_{\mathrm{I}}$ & $\mathrm{T}_{2}$ & $6.62 \pm 0.14$ & Level of significance \\
\hline $\mathrm{pH}$ & $6.76 \pm 0.12$ & $6.50 \pm 0.05$ & $6.71 \pm 0.01$ & $1.71^{\mathrm{b}} \pm 0.10$ & $*$ \\
\hline $\mathrm{C} \%$ & $1.64^{\mathrm{b}} \pm 0.06$ & $2.03^{\mathrm{a}} \pm 0.01$ & $1.61^{\mathrm{b}} \pm 0.1$ & $0.15^{\mathrm{b}} \pm 0.01$ & NS \\
\hline $\mathrm{N} \%$ & $0.14^{\mathrm{b}} \pm 0.00$ & $0.17^{\mathrm{a}} \pm 0.00$ & $0.13^{\mathrm{b}} \pm 0.00$ & $11.41 \pm 0.54$ & $* *$ \\
\hline $\mathrm{P}, \mathrm{ppm}$ & $11.59 \pm 0.49$ & $9.46 \pm 1.15$ & $11.80 \pm 0.69$ & $27.32^{\mathrm{b}} \pm 1.18$ & $* *$ \\
\hline $\mathrm{K}, \mathrm{ppm}$ & $23.62^{\mathrm{c}} \pm 0.63$ & $35.54^{\mathrm{a}} \pm 1.06$ & $23.62^{\mathrm{c}} \pm 1.21$ & $6.78^{\mathrm{b}} \pm 0.61$ & \\
\hline $\mathrm{S}, \mathrm{ppm}$ & $3.34^{\mathrm{c}} \pm 0.33$ & $8.83^{\mathrm{a}} \pm 0.63$ & $4.48^{\mathrm{c}} \pm 0.57$ & & \\
\hline
\end{tabular}

Mean values having different superscript in the same row differ significantly. ppm= parts per million, *, P<0.05; **, $\mathrm{P}<0.01 ; \mathrm{NS}$, Non-significant. T ${ }_{0}$-Control, T 1 -Struvite Compost @ 10MT/ha, T 2 -Cowdung @ 10MT/ha, T $\mathrm{T}_{3}$-Urea@ 250kg/ha.

\section{Conclusion}

It can be concluded that struvite compost can be more used for maize fodder production because of having high biomass yield and it can also be used for environment control through carbon sequestration.

\section{References}

AOAC, 1990. Official Methods of Analysis $\left(15^{\text {th }}\right.$ edn.). Association of Official Analytical Chemists, Washington, D.C.

BBS, 2005. Statistical Yearbook of Bangladesh. Ministry of Planning Government of the Peoples Republic of Bangladesh.

Dhiman, S. S.; Rammohan, D.S. and Sharma, A.G. 1982. Evaluation of nitrogen requirement for triple dwarf wheat. Indian J. Agron., 27(4): 387-392.

Hammam, G. V. 1995. Effect of nitrification inhibitor and nitrogen level on growth and yield of maize. Annals. Agril. Sci. Moshtohor., 33(2): 495-506.

Haque, M. M. 2003. Variety development of maize and its characteristics in Bangladesh. Production and Uses of Maize in Bangladesh. Published by BARI, CIMMYT and Integrated Maize Development Project, Bangladesh, pp. 1722.

Khandaker, Z. H. and Islam, M. M. 1998. Effect of nitrogen fertilization and stages of maturity on yield and quality of fodder maize. Bangladesh J. Anim. Sci., 17(1-2): 47-53.
Rahman, M. M.; Mohd, M. A.; Salleh, Rashid, U.; Ahsan, A.; Hossain, M. M. and Chang Six Ra. 2014. Production of slow release crystal fertilizer from wastewaters through struvite crystallization - A review. Arabian Journal of Chemistry, (7): 139-155.

Razende, G. M. de.; Silva, G. L. da. da.; Paiva, L. E.; Das, P. F.; Carvalho, J. G. de.; De Razende, G. M.; Da Silva, G. L. and De-Carvalho, J. G. 1994. Response of maize to nitrogen and potassium fertilizer application on some agronomic characteristics. $G$ Ciencia-ePratrica., 18(1):403-407. [Computer Search, CAB Abst. 2000-2001].

Reddy, A., Raguln, T. M. M., Ramaiah, N. V. and Reddy, G. V. 1987. Effect of methods of planting and nitrogen levels on growth, yield attributes and yield of rice under late condition. J. Res. Andhra Pradesh Agric. Univ., 15(1): 50-56.

Tareque, A. M. M. 1992. Feeds and fodder resources in Bangladesh and their pattern of utilization. ADB Second Livestock Project, TA-No. 668, BAN. 